\title{
Targeted and untargeted lipidomics of Emiliania huxleyi viral infection and life cycle phases highlights molecular biomarkers of infection, susceptibility, and ploidy
}

\author{
Jonathan E. Hunter ${ }^{1,2 *}$, Miguel J. Frada ${ }^{3}$, Helen F. Fredricks ${ }^{4}$, Assaf Vardi ${ }^{3}$ and \\ Benjamin A. S. Van Mooy ${ }^{4}$
}

${ }^{1}$ Ocean and Earth Science, National Oceanography Centre, University of Southampton, Southampton, UK, ${ }^{2}$ Institute for Life Sciences, University of Southampton, Southampton, UK, ${ }^{3}$ Department of Plant and Environmental Sciences, Weizmann Institute of Science, Rehovot, Israel, ${ }^{4}$ Department of Marine Chemistry and Geochemistry, Woods Hole Oceanographic Institution, Woods Hole, MA, USA

\section{OPEN ACCESS}

Edited by:

Anton F. Post,

Coastal Resources Center, University

of Rhode Island, USA

Reviewed by:

Kathleen Scott,

University of South Florida, USA

Joaquin Martinez Martinez,

Blgelow Laboratory for Ocean

Sciences, USA

*Correspondence: Jonathan E. Hunter

j.hunter@soton.ac.uk

Specialty section: This article was submitted to

Aquatic Microbiology,

a section of the journal

Frontiers in Marine Science

Received: 20 May 2015 Accepted: 25 September 2015

Published: 13 October 2015

Citation:

Hunter JE, Frada MJ, Fredricks HF, Vardi A and Van Mooy BAS (2015)

Targeted and untargeted lipidomics of

Emiliania huxleyi viral infection and life cycle phases highlights molecular

biomarkers of infection, susceptibility, and ploidy. Front. Mar. Sci. 2:81. doi: 10.3389/fmars.2015.00081
Marine viruses that infect phytoplankton strongly influence the ecology and evolution of their hosts. Emiliania huxleyi is characterized by a biphasic life cycle composed of a diploid $(2 \mathrm{~N})$ and haploid $(1 \mathrm{~N})$ phase; diploid cells are susceptible to infection by specific coccolithoviruses, yet haploid cells are resistant. Glycosphingolipids (GSLS) play a role during infection, but their molecular distribution in haploid cells is unknown. We present mass spectrometric analyses of lipids from cultures of uninfected diploid, infected diploid, and uninfected haploid E. huxleyi. Known viral GSLs were present in the infected diploid cultures as expected, but surprisingly, trace amounts of viral GSLs were also detected in the uninfected haploid cells. Sialic-acid GSLs have been linked to viral susceptibility in diploid cells, but were found to be absent in the haploid cultures, suggesting a mechanism of haploid resistance to infection. Additional untargeted high-resolution mass spectrometry data processed via multivariate analysis unveiled a number of novel biomarkers of infected, non-infected, and haploid cells. These data expand our understanding on the dynamics of lipid metabolism during E. huxleyi host/virus interactions and highlight potential novel biomarkers for infection, susceptibility, and ploidy.

Keywords: Emiliania huxleyi, lipidomics, coccolithovirus, glycosphingolipid, glycerolipids, haploid

\section{INTRODUCTION}

Emiliania huxleyi (Lohmann) is the numerically dominant coccolithophore in the modern oceans and an important component of phytoplankton assemblages, inhabiting all but extreme polar oceans. Moreover, it forms large, dense blooms in high-latitude coastal and shelf ecosystems that exert a critical impact upon the global carbon cycle and the earth's climate (Westbroek et al., 1993; Paasche, 2001; Tyrrell and Merico, 2004). In later stages these blooms become visible to satellites as large scale cell death leads to the mass shedding of the highly scattering calcium carbonate coccoliths that normally coat the surface of E. huxleyi cells (Holligan et al., 1983; Vardi et al., 2012; Lehahn et al., 2014). 
Marine viruses are the most abundant biological agents in the oceans (Fuhrman, 1999; Suttle, 2007). Specific, giant, lytic double-stranded DNA E. huxleyi viruses (EhV), belonging to the phycodnaviridae family that infect microalgae (Van Etten et al., 2002) are heavily implicated in the decay of E. huxleyi blooms (Bratbak et al., 1993; Brussaard et al., 1996; Vardi et al., 2012; Lehahn et al., 2014). Viruses that induce host cell lysis are thought to release particulate carbon and other nutrients into the water column (the "viral shunt"), thus circumventing the export of particulate organic matter to the deep ocean by way of the biological pump (Fuhrman, 1999; Suttle, 2007; Jover et al., 2014). Conversely, viral infection is also known to induce increased production of transparent exopolymer particles (TEP) in E. huxleyi, that accelerate the formation of sinking particulates, enhancing the biological pump, and removing virus particles from the upper water column (Vardi et al., 2012). The efficacy of the biological pump, and thus the effect of viruses on phytoplankton, has direct implications upon atmospheric carbon dioxide (Suttle, 2007).

At the cellular level, as a large dsDNA virus with high metabolic demand for the building blocks of DNA, lipids and protein synthesis, EhV triggers a rapid remodeling of the host metabolism (Rosenwasser et al., 2014; Schatz et al., 2014). In particular, recent studies have highlighted the crucial role of membrane lipids in the progression and regulation of EhV infection (Vardi et al., 2009, 2012; Rosenwasser et al., 2014). Evidence from genome and microscopic investigation suggests that EhV86 utilizes an animal-like, membrane-dependent infection strategy. EhV entry, by membrane fusion or endocytosis and the acquisition of host membrane lipids via budding (Mackinder et al., 2009; Schatz et al., 2014), seem to be localized to membrane lipid raft regions (Rose et al., 2014). Furthermore, the EhV genome contains a cluster of genes composing a nearly complete sphingolipid biosynthetic pathway analogous to the host pathway (Wilson et al., 2005; Monier et al., 2009).

Glycosphingolipids (GSLs) bearing a sphingoid base derived from palmitoyl-CoA-host glycosphingolipids (hGSL) - are abundant in uninfected E. huxleyi. Under lytic infection however, viral glycosphingolipids (vGSLs) derived from myristoyl-CoA are synthesized de novo, and vGSLs are known to play a role in the regulation of cell death in infected cells and are enriched in the membrane of newly formed virions (Vardi et al., 2009; Fulton et al., 2014; Rosenwasser et al., 2014). These vGSLs were detected in coccolithophore populations in the North Atlantic, which highlights their potential as biomarkers for viral infection in the oceans (Vardi et al., 2009, 2012).

A glycosphingolipid with a sialic acid modified glycosyl headgroup (sGSL) was recently described to have a direct relationship with susceptibility to infection. Across 11 strains of E. huxleyi (Fulton et al., 2014), sGSL was only detected at greater than trace levels in susceptible host strains, but not in viralresistant host strains. Given the presence of a sialidase gene in the EhV genome (Wilson et al., 2005), it has been speculated that sGSL is a target for hydrolysis by EhV sialidases and/or a ligand for attachment by EhV lectin proteins during infection (Fulton et al., 2014). This mechanism is of an analogous fashion to a range of human viral pathogens including influenza (Stray et al.,
2000). Additionally, betaine-like glycerolipids (BLL) were also recently described whose fatty acid composition appears highly indicative of the progression of infection. It was reported that uninfected E. huxleyi BLL composition was almost exclusively C16:0/C22:6 and C18:1/C22:6, while under viral infection the total BLL composition shifted to contain 50\% C22:6/22:6 (Fulton et al., 2014).

A basic feature of E. huxleyi is the possession of a biphasic, haplodiplontic, and heteromorphic life cycle comprising a diploid $(2 \mathrm{~N})$ coccolith-bearing phase that is non-motile and involved in the formation of blooms and a contrasting haploid $(1 \mathrm{~N})$ form bearing flagella and non-mineralized organic bodyscales (Green et al., 1996; Houdan et al., 2004). The vast majority of research on E. huxleyi has been conducted with $2 \mathrm{~N}$ cells, and yet recent transcriptomic analyses have revealed a dramatic differentiation between $1 \mathrm{~N}$ and $2 \mathrm{~N}$ cells, with less than $50 \%$ of transcripts estimated to be shared between the two phases, unraveling a deep degree of physiological segregation (Von Dassow et al., 2009; Rokitta et al., 2011). Interestingly, whilst the $2 \mathrm{~N}$ form is generally susceptible to EhV infection, the $1 \mathrm{~N}$ form appears completely resistant to EhV (Frada et al., 2008). Furthermore, when $2 \mathrm{~N}$ E. huxleyi are subject to $\mathrm{EhV}$ infection, a transition toward the resistant $1 \mathrm{~N}$ flagellated form is induced, likely allowing for continuity of E. huxleyi following viral bloom termination (Frada et al., 2008, 2012).

Given the central role that membrane lipids play in the progression and regulation of EhV infection and the resistance to EhV infection exhibited by $1 \mathrm{~N}$ E. huxleyi, a number of questions arise that are as yet unanswered. Early targeted analyses have shown similar compositions with respect to the major structural lipids, storage lipids, and pigments between $1 \mathrm{~N}$ and $2 \mathrm{~N}$ cells in the case of a single strain of E. huxleyi (Bell and Pond, 1996). Minor or novel lipid classes however, are as yet uncharacterized in the $1 \mathrm{~N}$ cell lipidome and it is unknown whether the susceptibility marker sGSL is absent from EhV resistant $1 \mathrm{~N}$ cells. By characterizing these lipids and the lipidome as a whole, we can gain insight into the mechanism of $1 \mathrm{~N} \mathrm{E}$. huxleyi resistance to $\mathrm{EhV}$ infections and potentially highlight biomarkers of each of the life cycle phases.

We present herein, a detailed characterization of the lipidomes of cultured E. huxleyi, an uninfected 2N strain (RCC 1216), the $2 \mathrm{~N}$ strain under infection with coccolithovirus (RCC $1216+$ EhV201), and an uninfected 1N strain (RCC 1217). Total lipid extracts derived from these cultures collected over $120 \mathrm{~h}$ postinfection were characterized by mass spectrometry. We used two approaches, targeted analysis for quantification of known GSL/glycerolipid species and untargeted analyses for screening for unknown lipids.

\section{MATERIALS AND METHODS}

\section{Culturing Procedures}

The calcifying, 2N Emiliania huxleyi strain RCC1216 and the non-calcified, flagellated $1 \mathrm{~N}$ E. huxleyi RCC1217 (isolated from RCC1216 following a partial phase change $(2 \mathrm{~N}$ to $1 \mathrm{~N})$, were used for this study (Houdan et al., 2005). Cells were cultured 
in $\mathrm{K} / 2$ medium (Keller et al., 1987) and incubated at $18^{\circ} \mathrm{C}$ with a $16: 8 \mathrm{~h}$, light: dark illumination cycle. Light intensity was provided at $100 \mu \mathrm{mol}$ photons $\mathrm{m}^{-2} \mathrm{~s}^{-1}$ with cool white LED lights. All experiments were performed in duplicate. The virus used for this study is the lytic E. huxleyi virus EhV201 (Schroeder et al., 2002) used at an initial multiplicity of infection (MOI) of 0.2 viral particles cell ${ }^{-1}$. Samples of $25 \mathrm{~mL}$ were collected daily over $120 \mathrm{~h}$ post-infection by gentle vacuum-filtration onto precombusted GFF filters (Whatmann) and stored at $-80^{\circ} \mathrm{C}$ until further analysis.

\section{Targeted Lipid Analysis}

Lipid abbreviations as indicated in the results section. Total lipid extracts were prepared from the cell isolates by a modified Bligh and Dyer extraction (Bligh and Dyer, 1959; Popendorf et al., 2013), with addition of the internal standard DNP-PE(16:0/16:0) (2,4-dinitrophenyl modified PE). The prepared total lipid extracts were then subjected to targeted lipid analysis by normal phase high performance liquid chromatography tandem mass spectrometry (HPLC-MS/MS) on an Agilent 1200 HPLC coupled to a Thermo Scientific TSQ Vantage triple quadrupole MS. Chromatography and mass spectrometry conditions were as described by Popendorf et al. (2013).

Lipid classes were identified by retention time and characteristic $\mathrm{MS}^{2}$ fragmentation (Popendorf et al., 2013; Fulton et al., 2014) and quantified based upon peak area within a given $\mathrm{MS}^{2}$ mass chromatogram. Quantification was achieved relative to external standard response factor calibrations. These calibrations were generated immediately before each analytical run, from a mixture of standards in a dilution series. PC, PG, PE, and DNP-PE (Avanti Polar Lipids, Alabaster, AL, USA); MGDG, DGDG (Matreya LLC, Pleasant Gap, PA, USA), and SQDG (Lipid Products, South Nutfield, UK) standards were used to generate calibrations for the glycerolipids. DGCC was quantified based on a purified extract from cultured Thalassiosira Pseudonana (Popendorf et al., 2013). DGTS was quantified based upon the DGCC calibration subject to a scaling factor (Popendorf et al., 2011b). The internal standard mixture was run after every seven samples as a control upon instrument variability. Quantities were corrected based upon the quality control run prior to a given sample. BLL and PDPT were quantified directly from the DNP-PE internal standard, as a semi-quantitative solution in the absence of an available internal standard. Quantification of hGSL, vGSL, and sGSL was based upon the response factor calibration of soy glucocerebroside extract (Avanti Polar Lipids, Alabaster, AL, USA) (Fulton et al., 2014).

While uninfected $1 \mathrm{~N}$ cells have been reported to have a smaller diameter than calcified uninfected $2 \mathrm{~N}$ cells, this difference is thought to be due primarily due to the presence of the calcified skeletons as opposed to large difference in cytoplasmic volume (Mausz and Pohnert, 2014). Furthermore, uncalcified 2N cells were found to be of comparable diameter to the $1 \mathrm{~N}$ cells (Klaveness, 1972; Mausz and Pohnert, 2014). Therefore, we assume that the biovolume of $1 \mathrm{~N}$ and $2 \mathrm{~N}$ cells was similar, and the measured lipid quantities were normalized to cell concentration for ease of interpretation.
All data represent the mean average of two biological replicates with error bars of one standard deviation. Statistical significance for the targeted analyses was determined by twotailed, paired equal-variance $T$-test. A Bonferroni correction was applied to the significance threshold to account for dual comparisons (uninfected $2 \mathrm{~N} /$ uninfected $1 \mathrm{~N}$, uninfected $2 \mathrm{~N} /$ infected $2 \mathrm{~N}$ ), thus a $p$-value of $<0.025$ was considered statistically significant. Any such significant variation is described in the results section. $P$-values were indicated as ${ }^{*} p<0.025$; ** $p<0.0025$ where appropriate.

\section{Untargeted Lipid Analysis}

Total lipid extracts from the $48 \mathrm{~h}$ samples were also analyzed by untargeted reverse phase HPLC-MS methodology on an Agilent 1200 HPLC coupled to a Thermo Scientific Exactive orbitrap high resolution mass spectrometer. Chromatography and mass spectrometry conditions were as described by Hummel et al. (2011) with the exception of a Waters XBridge C8 column ( $5 \mathrm{uM}$ packing, $150 \times 2.1 \mathrm{~mm}$ ). During each sample run, the mass spectrometer continuously cycled between full positive, full negative, positive all ion fragmentation, and negative all ion fragmentation modes, generating spectra with high mass accuracy.

The data was processed with the Thermo Scientific Sieve software package using the component extraction algorithm for chromatographic alignment, peak detection, and integration. Identified peak areas were then normalized to the DNP-PE internal standard and number of cells isolated. These unbiased analyses yield relative quantification; hence the abundance of a given molecular species is only comparable with the abundance of the same molecular species in other samples. The extracted data was filtered to remove molecular species where the deviation in abundance between replicates exceeded a factor of 10 .

Peak areas were mean centered, level scaled to their means (Van den Berg et al., 2006) and used to build a Partial Least Square Discriminant Analysis Model (PLS-DA), using the Classification Toolbox for MATLAB (Ballabio and Consonni, 2013). PLSDA models (Positive ions/Negative ions) were built using the following parameters: two components, Bayes assignment, six cross validation $(\mathrm{CV})$ groups in contiguous blocks (i.e., LeaveOne-Out validation as six samples were used). The positive model described $94 \%$ of the variance and had an error and CV error rate of 0 . The negative model described $89 \%$ of the variance and had an error and $\mathrm{CV}$ error rate of 0 . Ions from the mass spectrometry data were ranked upon their contribution (loading) toward the model score of samples of a given culture type (Supplementary Figure 2).

The top five ions ranked as indicative of each culture type in positive and negative ion mode were identified by matching to an extensive, accurate mass, structure query language (SQL) lipid database. The database was populated by permutations of fatty acids (chain length/degree of unsaturation) and common glycerolipids/sphingolipids. The complete LIPID MAPS (version 20130306) structural database (Sud et al., 2007) and MaConDa mass spectrometry contaminants database (Weber et al., 2012) were also included. The chemical formulae of database entries were then used to calculate accurate mass $\mathrm{m} / \mathrm{z}$ values based upon 
a list of common molecular ion adducts in ESI-MS (Huang et al., 1999). Database hits were within $2.5 \mathrm{ppm}$ of the measured $\mathrm{m} / \mathrm{z}$. Supporting $\mathrm{MS}^{2}$ fragmentation and diagnostic retention time information was recorded for the assignments presented in the Results and is included in Supplementary Figures 3, 4.

\section{RESULTS}

\section{Host Cell and Viral Dynamics and Relative Abundances}

Uninfected $2 \mathrm{~N}$ and uninfected $1 \mathrm{~N}$ cultures grew at a comparable average rate of $0.023 \mathrm{~h}^{-1}$, reaching a population density of $4.07 \times 10^{6} \pm 0.39 \times 10^{6}$ cells $\mathrm{mL}^{-1}$ and $4.79 \times 10^{6} \pm$ $0.28 \times 10^{6}$ cells $\mathrm{mL}^{-1}$ respectively within $120 \mathrm{~h}$ (Figure 1A). In contrast, the infected $2 \mathrm{~N}$ culture population peaked at $5.07 \times 10^{5}$ $\pm 1.15 \times 10^{4}$ cells $\mathrm{mL}^{-1}$ at $31 \mathrm{~h}$ and rapidly declined thereafter concomitant with the emergence of EhV particles in the medium. EhV concentration peaked at $54 \mathrm{~h}$ at $9.17 \times 10^{7} \pm 0.71 \times 10^{7}$ virions $\mathrm{mL}^{-1}$ in the infected $2 \mathrm{~N}$ cultures (Figure 1C). The decline phase was accompanied by an increase in the percentage of non-calcified (low scatter) cells from $17.70 \pm 0.73 \%$ at $0 \mathrm{~h}$ to $80.05 \pm 2.63 \%$ at $48 \mathrm{~h}$. Bacteria concentration (Figure 1D), whilst remaining low in the uninfected $2 \mathrm{~N}$ control, increased at a rate of $0.037 \mathrm{~h}^{-1}$ in the infected $2 \mathrm{~N}$ cultures after the onset of infection reaching a maximum of $1.15 \times 10^{7} \pm 8.39 \times 10^{5}$ cells $\mathrm{mL}^{-1}$ at $120 \mathrm{~h}$.

\section{Glycerolipid Targeted Lipidomics}

The polar glycerolipids phosphatidylcholine (PC), diacylglyceryl-3-O-carboxy-(hydroxymethyl)-choline (DGCC), digalactosyldiacylglycerol (DGDG), sulfoquinovosyldiacyl glycerol (SQDG), and the sulfur containing phospholipid phosphatidyl-S,S-dimethylpropanethiol (PDPT) (Fulton et al., 2014) did not vary between cultures (Supplementary Figure 1). However, several other classes of polar glycerolipid showed interesting differences.

Phosphatidylglycerol (PG) quantity per cell (Figure 2A) in the uninfected $2 \mathrm{~N}$ and uninfected $1 \mathrm{~N}$ cultures was statistically similar through time. PG per cell in the infected $2 \mathrm{~N}$ cultures initially declined by $0.27 \pm 0.023^{*}$ fold at $31 \mathrm{~h}$ relative to the uninfected $2 \mathrm{~N}$ control. A large increase in infected 2N PG per cell of 30.29 \pm 21.80 fold was observed at $120 \mathrm{~h}$, although relative to the uninfected $2 \mathrm{~N}$ control cultures the increase was not statistically significant $(p=0.12$ ), due to a large variation between the biological replicates at this time point.

Phosphatidylethanolamine (PE) quantity per cell (Figure 2B) showed a decreasing trend through time in the uninfected $1 \mathrm{~N}$ and uninfected $2 \mathrm{~N}$ cultures. $\mathrm{PE}$ was slightly elevated in the uninfected $1 \mathrm{~N}$ cultures compared to the uninfected $2 \mathrm{~N}$ control, this was statistically significant only at $24 \mathrm{~h}$, where PE per cell in the uninfected $1 \mathrm{~N}$ was $1.57 \pm 0.16^{*}$ fold higher than in uninfected $2 \mathrm{~N}$. PE quantity per cell in the infected $2 \mathrm{~N}$ cultures diverged from the uninfected $2 \mathrm{~N}$ control after $24 \mathrm{~h}$, progressively increasing to $4.58 \pm 0.18^{* *}$ fold greater at $54 \mathrm{~h}$. In common with PG, a large increase of infected $2 \mathrm{~N}$ PE per cell at $120 \mathrm{~h}$, of $180.10 \pm 105.19$ fold, was not statistically significant $(p=0.10)$, due to variability in the replicate samples at this time point.

Two non-phosphorous polar glycerolipids showed interesting and significant dynamics. Monogalactosyldiacylglycerol (MGDG) quantity per cell (Figure 2C) was statistically similar in all of the cultures before $52 \mathrm{~h}$, but showed a decreasing trend with time. However, at $120 \mathrm{~h} \mathrm{MGDG}$ in the infected $2 \mathrm{~N}$ cultures increased by $9.31 \pm 5.68^{*}$ fold, relative to the uninfected $2 \mathrm{~N}$ cultures. Diacylglyceryltrimethylhomoserine (DGTS) quantity per cell (Figure 2D) appeared to be approximately half as abundant in the uninfected $1 \mathrm{~N}$ compared with the uninfected $2 \mathrm{~N}$ control cultures at $0.55 \pm 0.12^{*}$ fold less at $24 \mathrm{~h}$ and $0.66 \pm$ $0.01^{* *}$ fold less at $48 \mathrm{~h}$. DGTS per cell in the infected $2 \mathrm{~N}$ cultures did not vary statistically significantly from the uninfected $2 \mathrm{~N}$ control, with the exception of a $1.29 \pm 0.02^{* *}$ fold increase at $48 \mathrm{~h}$. Similar to PG, DGTS levels in the uninfected $2 \mathrm{~N}$ and uninfected $1 \mathrm{~N}$ cultures remained relatively consistent through time.

Total Betaine-Like Lipid (BLL; Fulton et al., 2014) quantity per cell (Figure 3A) varied considerably in all cultures, ranging from a minimum of $35.55 \pm 21.35 \mathrm{amol} \mathrm{cell}^{-1}$ at $24 \mathrm{~h}$ in the uninfected $1 \mathrm{~N}$ cultures to a maximum of $86.07 \pm 27.21 \mathrm{amol}$

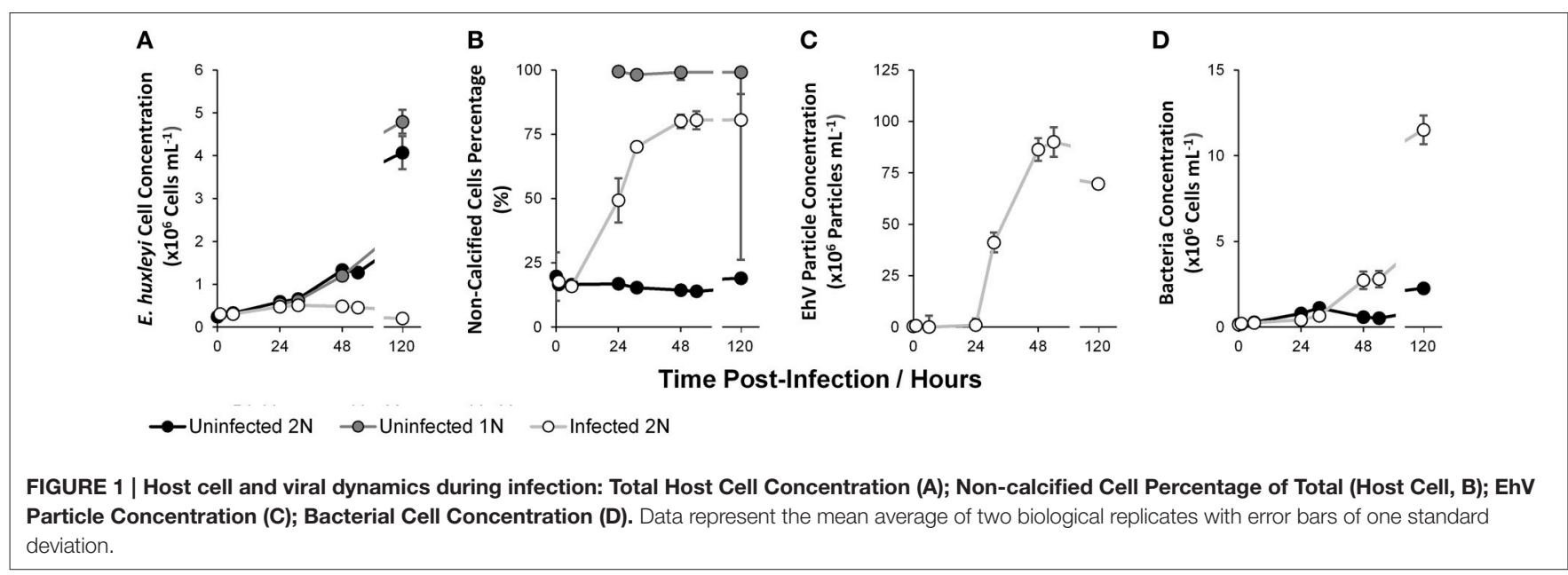



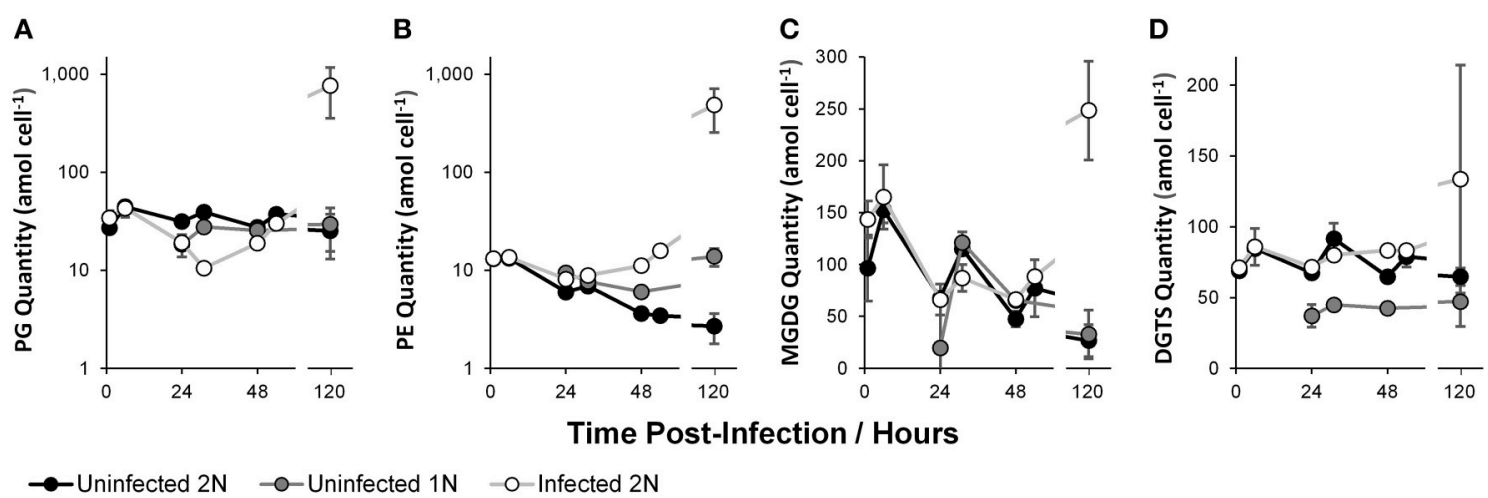

FIGURE 2 | Polar glycerolipid quantity per E. huxleyi cell: Phosphatidylglycerol (PG, A); Phosphatidylethanolamine (PE, B); Monogalactosyldiacylglycerol (MGDG, C); and Diacylglyceryltrimethylhomoserine (DGTS, D). Data represent the mean average of two biological replicates with error bars of one standard deviation. See Supplementary Table 1 for tabulated data.

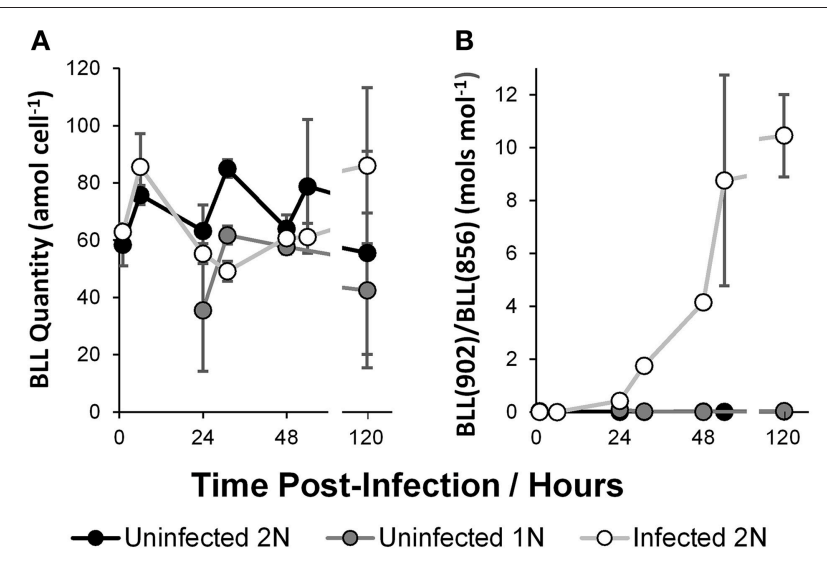

FIGURE 3 | Betaine-Like Lipid (BLL), total quantity per cell (A), and ratio of $B L L(902 ; 22: 6 / 22: 6)$ quantity to $B L L(856 ; 18: 1 / 22: 6)$ quantity $(B)$. Data represent the mean average of two biological replicates with error bars of one standard deviation. See Supplementary Table 1 for tabulated data.

cell $^{-1}$ at $120 \mathrm{~h}$ in the infected $2 \mathrm{~N}$ cultures. Only at $31 \mathrm{~h}$ were significant differences observed, where the infected $2 \mathrm{~N}$ cultures were $0.58 \pm 0.05$ fold less and the uninfected $1 \mathrm{~N}$ cultures were $0.73 \pm 0.05^{*}$ fold less than in the uninfected $2 \mathrm{~N}$ control. No clear trend was evident in the total BLL quantity per cell, in response to time or between the different cultures. However, the ratio between two BLL molecular species, BLL(22:6/22:6) and BLL(18:1/22:6) showed marked differences (Figure 3B). In the uninfected $2 \mathrm{~N}$ and uninfected $1 \mathrm{~N}$ cultures, the ratio was $<0.1$ throughout, representing the relative absence of $\operatorname{BLL}(22: 6 / 22: 6)$ compared to BLL(18:1/22:6) when uninfected. The ratio of these species rose rapidly under infection reaching $10.46 \pm 1.56$ at $120 \mathrm{~h}$ after inoculation of the infected $2 \mathrm{~N}$ cultures.

\section{Glycosphingolipid Targeted Lipidomics}

Concentrations of two classes of glycosphingolipids were highly dynamic through the course of infection. The infection marker viral glycosphingolipid (vGSL, Figure 4A) was abundant only in the infected $2 \mathrm{~N}$ cultures. Infected $2 \mathrm{~N}$ vGSL concentration rose consistently through time from absent at $0 \mathrm{~h}$ to $169.32 \pm$ $73.77 \mathrm{amol} \mathrm{cell}^{-1}$ at $120 \mathrm{~h}$, concomitant with the increase in $\mathrm{EhV}$ concentrations. Interestingly, lower levels of vGSL (4-8 amol cell $^{-1}$ ) were also detected in the uninfected $1 \mathrm{~N}$ cultures, reaching a maximum of $7.63 \pm 0.13$ amol cell ${ }^{-1}$ at $120 \mathrm{~h}$.

The susceptibility marker sialic glycosphingolipid (sGSL, Figure 4C) was abundant in the uninfected $2 \mathrm{~N}$ control, with no clear time dependence, between a range of $132.32 \pm 4.09$ amol cell ${ }^{-1}$ at $24 \mathrm{~h}$ and $193.76 \pm 3.20 \mathrm{amol} \mathrm{cell}^{-1}$ at $6 \mathrm{~h}$. The concentrations of sGSL in the infected $2 \mathrm{~N}$ cultures displayed an approximately decreasing trend from $191.07 \pm 35.35 \mathrm{amol} \mathrm{cell}^{-1}$ at $6 \mathrm{~h}$ to $51.59 \pm 0.57 \mathrm{amol}^{\text {cell }^{-1}}$ at $54 \mathrm{~h}$. Importantly, sGSL was absent from the uninfected $1 \mathrm{~N}$ cultures. In contrast to vGSL and sGSL, a third class of glycosphingolipid, the intrinsic host glycosphingolipid (hGSL, Figure 4B) presented no statistically significant variation between cultures, and no trend was evident with the progression of time.

\section{Untargeted Lipidomics and Biomarker Selection}

Untargeted lipidomic data were collected from the incubations at $48 \mathrm{~h}$ and subsequent PLS-DA analysis revealed a number of potential biomarkers for E. huxleyi life stages and viral infection. The top 5 loadings that were indicative for each culture type, bearing significant differences by univariate statistics $(p=<0.05$ by single factor ANOVA), were assigned by database matching (Table 1). All ion fragmentation $\mathrm{MS}^{2}$ data was used to confirm database hits (Supplementary Figures 3, 4).

The potential biomarkers for the $2 \mathrm{~N}$ control cultures were sGSLs, bearing various adducts and plus or minus one double bond resulting in the highest positive loadings on PC2. In positive ion mode (Table 1A), tentatively assigned sGSL $+\mathrm{H}_{2}$, sGSL- $\mathrm{H}_{2}$, and sGSL (with two different adducts) gave normalized abundances of $0.81,0.79,0.78$, and 0.72 respectively, where the sGSL of calculated $\mathrm{m} / \mathrm{z} 870.6665[\mathrm{M}+\mathrm{H}]^{+}$is regarded as the archetypal sGSL (Fulton et al., 2014). A $752.5226 \mathrm{~m} / \mathrm{z}$ species, with a database hit to $\mathrm{PC}(34: 5)$ showed a normalized abundance of 0.60 . In negative ion mode (Table 1B), sGSL $+\mathrm{H}_{2}$, sGSL and 
A

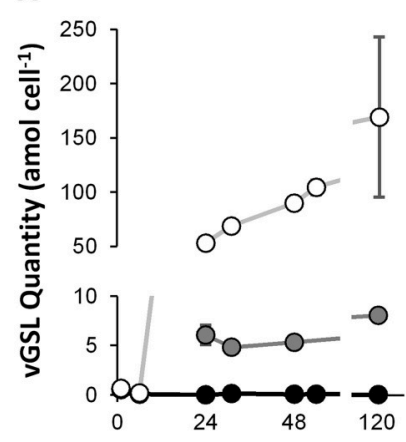

$\rightarrow-$ Uninfected $2 \mathrm{~N} \quad-\mathrm{O}$-Uninfected $1 \mathrm{~N} \quad-\mathrm{O}$-Infected $2 \mathrm{~N}$

B

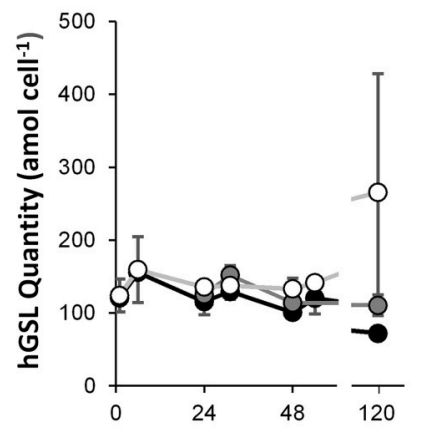

Time Post-Infection / Hours
C

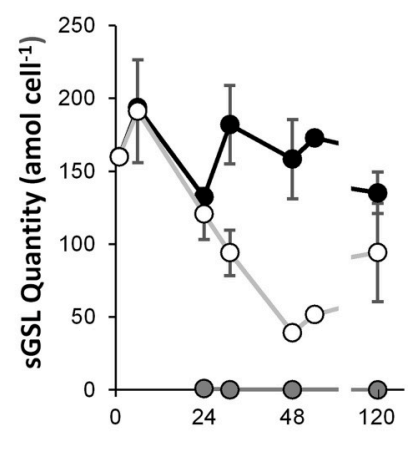

FIGURE 4 | Glycosphingolipid quantity per E. huxleyi cell: Viral glycosphingolipid (vGSL, A); Host glycosphingolipid (hGSL, B); Sialic-acid glycosphingolipid (sGSL, C). Data represent the mean average of two biological replicates with error bars of one standard deviation. See Supplementary Table 1 for tabulated data.

BLL(18:1/22:6) showed a normalized abundance of $0.82,0.79$, and 0.61 respectively. Species of $\mathrm{m} / \mathrm{z} 827.4963$ and 949.5362 with hits to MGDG(36:9) and SQDG(40:8) respectively showed normalized abundances of 0.60 and 0.58 .

The top potential biomarker for uninfected $1 \mathrm{~N}$ cells, in positive ion mode, was a wax ester/alkanoate WE(31:0) with two and one acetonitrile adducts, which was detected solely in the $1 \mathrm{~N}$ cultures yielding normalized abundances of 1.00 and 1.00 respectively. Two GSLs, GSL(t40:0) and GSL(t40:1), distinct to previously documented GSLs in the E. huxleyi host/virus system, had normalized abundances of 0.67 and 0.65 respectively. Finally, MGDG(32:5) was ranked fifth with a normalized abundance of 0.70 . In negative ion mode, a lyso-MGDG (bearing a single fatty acid rather than a pair), LMGDG(22:6) was most strongly indicative of the uninfected $1 \mathrm{~N}$ cultures with a normalized abundance of 0.87 . Ceramide species, chemically similar to sGSL but lacking any headgroup and bearing a hydroxy fatty amide, $\operatorname{Cer}(\mathrm{d} 18: 1 / 22: 0(\mathrm{OH}))$, and $\operatorname{Cer}(\mathrm{d} 18: 1 / 22: 1(\mathrm{OH}))$ in the uninfected $1 \mathrm{~N}$ cultures had normalized abundances of 0.70 and 0.61 respectively. Lastly, digalactosyldiacylglycerols and DGDG(32:5) and DGDG(30:6) were enriched in the uninfected $1 \mathrm{~N}$ cultures with normalized abundances of 0.71 and 0.69 respectively.

The potential biomarkers for the infected $2 \mathrm{~N}$ cells were highly diagnostic, with 7 out of the top 10 yielding normalized abundances of 1.00. In positive ion mode, a series of triacylglycerols (TAGs) gave the highest negative loadings on PC1 and were ranked highest. TAG(50:6); TAG(51:4); TAG(46:1); TAG(48:2); and TAG(51:5) each had normalized abundances of 1.00. In negative ion mode, previously described biomarkers vGSL (with a chloride adduct); vGSL; BLL(22:6/22:6); and vGSL $+\mathrm{CH}_{2}$ had normalized abundances of $1.00,1.00,0.98,0.97$, and 0.86 respectively, where vGSL of calculated $\mathrm{m} / \mathrm{z} 802.6414$ [M$\mathrm{H}]^{-}$is regarded as the archetypal vGSL (Vardi et al., 2009). A fatty acid/wax ester like FA/WE(36:2) species was ranked fifth in negative ion mode with a normalized abundance of 0.86 .
Further to the assigned species (Table 1) there were many molecular species of interest that could not be assigned by accurate mass database matching (Supplementary Table 2).

\section{DISCUSSION}

\section{Host Cell and Viral Dynamics and Relative Abundances}

Uninfected $2 \mathrm{~N}$ and uninfected $1 \mathrm{~N}$ E. huxleyi populations increased exponentially through time with a similar growth rate and maximum population, but the infected $2 \mathrm{~N}$ cultures peaked at $31 \mathrm{~h}$ and declined thereafter, consistent with typical lytic viral infection by EhV (Bratbak et al., 1993; Wilson et al., 2002) (Figure 1A). This decline was concomitant with a rapid increase in EhV particles and non-calcified, low side scatter E. huxleyi cell concentration in the growth media, indicating both viral burst from infected cells and the demise of $2 \mathrm{~N}$ calcified cells (Figures 1B,C). These growth dynamics reflect identical trends to those previously described (Frada et al., 2008, 2012). High scatter cells were predominate in the uninfected $2 \mathrm{~N}$ control, representing the coccolith bearing $2 \mathrm{~N}$ phase. Conversely, cells in the uninfected $1 \mathrm{~N}$ cultures were mostly low scatter, indicative of the non-calcifying $1 \mathrm{~N}$ phase.

The cultures used in this study were non-axenic, and a rapid increase in bacterial numbers in the infected $2 \mathrm{~N}$ cultures was likely fuelled by the release of organic carbon during cell lysis. However, in terms of overall biomass, the level of contamination from bacteria is comparatively minor: considering the cell concentrations of E. huxlyei and bacteria, and cellular carbon quotas of $2 \mathrm{pmol} \mathrm{C}$ cell $^{-1}$ and 1 fmol C cell ${ }^{-1}$, respectively (Gundersen et al., 2002; Borchard and Engle, 2012), E. huxleyi dominate biomass by approximately a factor of 20 . Based on the cell counts of the uninfected $2 \mathrm{~N}$ and uninfected $1 \mathrm{~N}$ cultures, we would expect this factor to be orders of magnitude higher. Thus, except in the case of a few specific lipid molecules (discussed 
TABLE 1 | Top 5 loadings (assigned species only) for each culture type in the PLS-DA model: Positive ions (A) and Negative ions (B).

\section{A - Positive lons}

\begin{tabular}{|c|c|c|c|c|c|c|c|c|c|}
\hline \multirow[b]{3}{*}{ Selection } & \multirow[b]{3}{*}{ Rank } & \multirow[b]{3}{*}{$M / Z$} & \multirow{3}{*}{$\begin{array}{l}\text { Retention } \\
\text { Time (Min) }\end{array}$} & \multirow[b]{3}{*}{ Identity } & \multirow[b]{3}{*}{ Adduct } & \multirow[b]{3}{*}{$\mathrm{P}$} & \multicolumn{3}{|c|}{ Normalised Abund ance } \\
\hline & & & & & & & Uninfected & infected & Infected \\
\hline & & & & & & & $2 \mathrm{~N}$ & & $2 \mathrm{~N}$ \\
\hline \multirow{5}{*}{$\begin{array}{l}\text { Uninfected } \\
2 \mathrm{~N}\end{array}$} & 1 & 872.6824 & 15.8 & $\mathrm{sGSL}+\mathrm{H}_{2}$ & $(\mathrm{M}+\mathrm{H})+$ & * & 0.81 & 0.00 & 0.19 \\
\hline & 2 & 868.6510 & 14.4 & SGSL - $\mathrm{H}_{2}$ & $(\mathrm{M}+\mathrm{H})+$ & * & 0.79 & 0.00 & 0.21 \\
\hline & 3 & 870.6666 & 15.2 & sGSL & $(M+H)+$ & * & 0.78 & 0.00 & 0.22 \\
\hline & 4 & 892.6484 & 15.3 & sGSL & $(\mathrm{M}+\mathrm{Na})+$ & * & 0.72 & 0.02 & 0.26 \\
\hline & 5 & 752.5226 & 12.3 & $\mathrm{PC}(34: 5)$ & $(\mathrm{M}+\mathrm{H})+$ & * & 0.60 & 0.15 & 0.25 \\
\hline \multirow{5}{*}{$\begin{array}{l}\text { Uninfected } \\
1 \mathrm{~N}\end{array}$} & 1 & 549.5356 & 15.3 & WE(31:0) & $(\mathrm{M}+2 \mathrm{AcN}+\mathrm{H})+$ & * & 0.00 & 1.00 & 0.00 \\
\hline & 2 & 508.5091 & 15.3 & WE $(31: 0)$ & $(\mathrm{M}+\mathrm{AcN}+\mathrm{H})+$ & ** & 0.00 & 1.00 & 0.00 \\
\hline & 3 & 802.6768 & 17.3 & GSL(t40:0) & $(\mathrm{M}+\mathrm{H})+$ & $* *$ & 0.04 & 0.67 & 0.29 \\
\hline & 4 & 800.6614 & 17.0 & GSL(t40:1) & $(\mathrm{M}+\mathrm{H})+$ & ** & 0.05 & 0.65 & 0.30 \\
\hline & 5 & 738.5155 & 11.9 & $\operatorname{MGDG}(32.5)$ & $(\mathrm{M}+\mathrm{NH} 4)+$ & $\star \star$ & 0.22 & 0.70 & 0.09 \\
\hline \multirow[t]{5}{*}{ Infected $2 \mathrm{~N}$} & 1 & 840.7079 & 18.2 & TAG(50:6) & $(\mathrm{M}+\mathrm{NH} 4)+$ & * & 0.00 & 0.00 & 1.00 \\
\hline & 2 & 858.7546 & 19.0 & $\operatorname{TAG}(51: 4)$ & $(\mathrm{M}+\mathrm{NH} 4)+$ & * & 0.00 & 0.00 & 1.00 \\
\hline & 3 & 799.6788 & 19.4 & TAG(46:1) & $(\mathrm{M}+\mathrm{Na})+$ & * & 0.00 & 0.00 & 1.00 \\
\hline & 4 & 885.7650 & 18.7 & TAG(50:4) & $(\mathrm{M}+\mathrm{AcN}+\mathrm{NH} 4)+$ & * & 0.00 & 0.00 & 1.00 \\
\hline & 5 & 856.7391 & 18.6 & $\operatorname{TAG}(51: 5)$ & $(\mathrm{M}+\mathrm{NH} 4)+$ & * & 0.00 & 0.00 & 1.00 \\
\hline
\end{tabular}

\section{B - Negative lons}

\begin{tabular}{|c|c|c|c|c|c|c|c|c|c|}
\hline \multirow{5}{*}{$\begin{array}{l}\text { Uninfected } \\
2 \mathrm{~N}\end{array}$} & 1 & 870.6694 & 15.8 & $\mathrm{sGSL}+\mathrm{H}_{2}$ & $(\mathrm{M}-\mathrm{H})-$ & $*$ & 0.82 & 0.00 & 0.18 \\
\hline & 2 & 868.6532 & 15.2 & sGSL & $(\mathrm{M}-\mathrm{H})-$ & * & 0.79 & 0.00 & 0.21 \\
\hline & 3 & 854.5800 & 12.6 & BLL(18:1/22:6) & $(\mathrm{M}-\mathrm{H})-$ & * & 0.61 & 0.27 & 0.13 \\
\hline & 4 & 827.4963 & 10.9 & MGDG(36:9) & $(\mathrm{M}+\mathrm{HAc}-\mathrm{H})-$ & $* *$ & 0.60 & 0.23 & 0.17 \\
\hline & 5 & 949.5362 & 14.9 & SQDG(40:8) & $(\mathrm{M}+\mathrm{HAC}-\mathrm{H})-$ & $* *$ & 0.58 & 0.26 & 0.16 \\
\hline \multirow{5}{*}{$\begin{array}{l}\text { Uninfected } \\
1 \mathrm{~N}\end{array}$} & 1 & 623.3450 & 6.2 & LMGDG(22:6) & $(\mathrm{M}+\mathrm{HAC}-\mathrm{H})-$ & * & 0.06 & 0.87 & 0.08 \\
\hline & 2 & 696.6158 & 17.3 & $\operatorname{Cer}(\mathrm{d} 18: 1 / 22: 0(\mathrm{OH}))$ & $(\mathrm{M}+\mathrm{HAc}-\mathrm{H})-$ & $* *$ & 0.03 & 0.70 & 0.27 \\
\hline & 3 & 694.6004 & 17.1 & $\operatorname{Cer}(\mathrm{d} 18: 1 / 22: 1(\mathrm{OH}))$ & $(\mathrm{M}+\mathrm{HAc}-\mathrm{H})-$ & $* *$ & 0.06 & 0.61 & 0.33 \\
\hline & 4 & 941.5497 & 11.2 & DGDG(32:5) & $(\mathrm{M}+\mathrm{HAC}-\mathrm{H})-$ & * & 0.19 & 0.71 & 0.11 \\
\hline & 5 & 833.4686 & 12.0 & DGDG(30:6) & $(\mathrm{M}-\mathrm{H} 2 \mathrm{O}-\mathrm{H})-$ & * & 0.22 & 0.69 & 0.09 \\
\hline \multirow{5}{*}{ Infected $2 \mathrm{~N}$} & 1 & 838.6196 & 16.3 & vGSL & $(\mathrm{M}+\mathrm{Cl})-$ & $* *$ & 0.00 & 0.00 & 1.00 \\
\hline & 2 & 802.6404 & 16.3 & vGSL & $(\mathrm{M}-\mathrm{H})-$ & $\star \star \star$ & 0.00 & 0.00 & 1.00 \\
\hline & 3 & 900.5646 & 10.9 & BLL(22:6/22:6) & $(\mathrm{M}-\mathrm{H})-$ & $* *$ & 0.01 & 0.01 & 0.98 \\
\hline & 4 & 816.6564 & 16.7 & vGSL $+\mathrm{CH}_{2}$ & $(\mathrm{M}-\mathrm{H})-$ & $* *$ & 0.00 & 0.03 & 0.97 \\
\hline & 5 & 531.5149 & 18.0 & WE(36:2) & $(\mathrm{M}-\mathrm{H})-$ & $\star \star *$ & 0.06 & 0.07 & 0.86 \\
\hline
\end{tabular}

Normalized abundance represents the average abundance of an ion in the specified culture type divided by the total abundance of that ion in all three cultures. M/Z represents the mass to charge ratio of a given molecular ion. AcN and HAc represent acetonitrile and acetate adducts respectively. ${ }^{*} p=<0.05,{ }^{* *} p=<0.005$ by single factor ANOVA.

below) we would expect the lipidomes of our samples to be overwhelmingly dominated by contributions from E. huxleyi.

\section{Glycerolipid Targeted Lipidomics}

For the most part, polar glycerolipids per cell were largely invariant between cultures and with time, with only a few notable exceptions. Despite the relatively small contributions of bacterial biomass, the observed increase in PG concentration in the infected $2 \mathrm{~N}$ cultures (Figure 2A) was most likely due to an increase in the bacterial population (Figure 1D). Thus, this result is not entirely unexpected since PG generally composes about half of the glycerolipids in marine bacteria, while in E. huxleyi PG only 
represents $0.2 \%$ of the lipidome (Fulton et al., 2014; Carini et al., 2015).

In the infected $2 \mathrm{~N}$ cultures, $\mathrm{PE}$ quantity also increased compared to the uninfected $2 \mathrm{~N}$ control after $24 \mathrm{~h}$ (Figure 2B). Like PG, PE is also a major component of bacterial membranes but is scarce in E. huxleyi (Van Mooy et al., 2009; Popendorf et al., 2011a; Carini et al., 2015), and thus a contribution from bacteria is possible (Fulton et al., 2014). Alternatively, this increase in PE may be derived from the host cell's autophagy machinery (Schatz et al., 2014). Autophagy is a highly conserved eukaryotic mechanism for the degradation of damaged organelles and unwanted macromolecules (Shemi et al., 2015). It has been demonstrated that autophagy is induced during the lytic phase of EhV infection and plays a role in the propagation of the virus (Schatz et al., 2014). A well-known hallmark of autophagy is PE lipidation of the Atg8 protein, as also reported in E. huxleyi under EhV infection (Schatz et al., 2014). Thus, the observed increase in $\mathrm{PE}$ under EhV infection may be attributable to the induction of autophagy via lipidation of the Atg8 protein. Interestingly, total $\mathrm{PE}$ appeared slightly more abundant per cell in the uninfected $1 \mathrm{~N}$ cultures, relative to the uninfected $2 \mathrm{~N}$ control.

MGDG quantity per cell was similar between uninfected $2 \mathrm{~N}$ and uninfected $1 \mathrm{~N}$ cultures, while the infected $2 \mathrm{~N}$ cultures showed a large increase in MGDG quantity per cell at $120 \mathrm{~h}$ post-inoculation (Figure 2C). MGDG is often associated with the thylakoid membranes of the chloroplast (Sakurai et al., 2006) and hence variation may indicate a consequence of infection upon the host photosynthetic machinery. In contrast, a decrease in MGDG under EhV infection of E. huxleyi has been shown elsewhere (Fulton et al., 2014). Furthermore, a recent study on another haptophyte Haptolina ericina infected with a dsDNA virus observed a decrease in glycolipid abundance under infection (Ray et al., 2014). This decrease was suggested to derive from cell disruption during infection, resulting in a loss of chloroplasts during sample preparation. The haptophyte Phaeocystis pouchetii did not display a major loss of cellular MGDG when infected with a dsDNA virus (Ray et al., 2014). MGDG is one of the most abundant lipids in E. huxleyi (Fulton et al., 2014), but this molecule is scarce in bacteria because they have a clear preference for synthesizing phospholipids over glycolipids when phosphate is abundant, as in the $\mathrm{K} / 2$ medium used here (Popendorf et al., 2011a; Carini et al., 2015); thus, it is unlikely that the MGDG observed in the infected $2 \mathrm{~N}$ cultures is of bacterial origin. Clearly at this stage we have an incomplete understanding of the behavior of MGDG under viral infection in haptophytes such as E. huxleyi.

Total DGTS abundance per cell in the uninfected $1 \mathrm{~N}$ cultures was consistently around half of its abundance in the uninfected $2 \mathrm{~N}$ control (Figure 2D). Betaine lipids such as DGTS are known to substitute for membrane phospholipids (primarily PC) under phosphorus stress in many eukaryotic phytoplankton. As such the $\mathrm{BL} / \mathrm{PC}$ ratio has been considered as a measure for phosphorus limitation in the environment (Van Mooy et al., 2009; Martin et al., 2011). Reduced DGTS abundance from $1 \mathrm{~N}$ cells within an environmental population would impact such a measure. Furthermore, when coupled with a slight increase in PE in the $1 \mathrm{~N}$ case, outlined earlier, this may shift the glycerolipid stoichiometry to an $\mathrm{N}$ : $\mathrm{P}$ ratio lower than the $2 \mathrm{~N}$ counterpart (Van Mooy et al., 2009; Carini et al., 2015).

Whilst total BLL quantity per cell was generally similar (Figure 3A), BLL(22:6/22:6) was present only at trace level in the uninfected $2 \mathrm{~N}$ cultures and increased dramatically in abundance in the infected $2 \mathrm{~N}$ cultures. $\operatorname{BLL}(18: 1 / 22: 6)$ was present in the uninfected $2 \mathrm{~N}$ and uninfected $1 \mathrm{~N}$ cultures and we found that the ratio between $\operatorname{BLL}(22: 6 / 22: 6) / \operatorname{BLL}(18: 1 / 22: 6)$ was a strong indicator of infection in these experiments (Figure 3B). We suggest that in light of these and previous observations (Fulton et al., 2014), that BLL(22:6/22:6) and ratios thereof may be a useful biomarker of $\mathrm{EhV}$ infection to compliment vGSL. Application as a biomarker would require further investigation to verify $\operatorname{BLL}(22: 6 / 22: 6)$ presence/absence under the infected/host states is conserved across different E. huxleyi and viral strains and specific to E. huxleyi. The presence/absence relationship has been to date demonstrated in E. huxleyi $1216(2 \mathrm{~N}), 1217(1 \mathrm{~N})$, and 1216 with EhV201 in this study and E. huxleyi $374(2 \mathrm{~N})$ with EhV86 (Fulton et al., 2014).

Notably, the polar glycerolipids PC, DGCC, DGDG, SQDG, and PDPT were effectively identical in all three cultures through time (Supplementary Figure 1). This observation, in conjunction with the many similarities in PG, PE, and MGDG indicates that the overall polar glycerolipid content is not radically affected by life cycle or even viral infection, except potentially at the very termination of the lytic phase; only DGTS and BLL (22:6/22:6) show notable earlier variations. Bell and Pond (1996) observed that the distributions of fatty acids within polar glycerolipids were also fairly similar in uninfected $2 \mathrm{~N}$ and $1 \mathrm{~N}$ cells. Thus, overall these molecules seem to play a largely passive role in life cycle differentiation and infection. Furthermore, since the cellular lipid content of the major glycerolipids is mostly similar in all three cultures and cellular lipid content is a first-order approximation of cellular biomass, these data validate our assumption that the different types of cells do not vary greatly in size (i.e., biomass content) and support our decision to normalize all lipid data to cell abundance.

\section{Glycosphingolipid Targeted Lipidomics}

In contrast to the polar glycerolipids, the glycosphingolipids were highly dynamic, showing marked differences between culture treatments and through time. The infection marker vGSL was absent from the uninfected $2 \mathrm{~N}$ cultures and abundant in the infected $2 \mathrm{~N}$ cultures, rising through time with the progression of infection (Figure 4A), in agreement with previous observations (Vardi et al., 2009, 2012). Interestingly, low levels of vGSLlike molecules were detected in the uninfected $1 \mathrm{~N}$ cultures. These vGSL-like species produce the same diagnostic glycosyl headgroup fragments and co-elute with previously characterized vGSLs. Untargeted lipidomic data, discussed below, suggest however that these molecules may not be exactly the same as the vGSLs in the infected diploid cultures originally recognized by Vardi et al. (2009). Future developments in targeted lipidomic methods hold the promise of being able to distinguish true vGSL from infected diploid cells and this novel vGSL-like molecule from uninfected haploid cells. 
Host intrinsic hGSL did not vary in quantity per cell between the uninfected $2 \mathrm{~N}$ control and the infected $2 \mathrm{~N}$ cultures, in line with previous studies (Vardi et al., 2009, 2012; Fulton et al., 2014). Furthermore, we find that hGSL cellular abundance is also statistically similar in the uninfected $1 \mathrm{~N}$ cultures (Figure 4B).

The marker lipid sGSL was recently described as indicative of susceptibility to viral infection in E. huxleyi (Fulton et al., 2014) and we found that sGSL was abundant in the virussusceptible $2 \mathrm{~N}$ strain used in this study, RCC1216. Levels of sGSL were somewhat reduced with the progression of infection in the infected $2 \mathrm{~N}$ cultures at intermediate time, before returning to a level statistically similar to that of the uninfected control (Figure 4C). This contrasts with a previous study with a different E. huxleyi strain (Fulton et al., 2014) showing an increase in sGSL cellular abundance under infection. The same report however, included mesocosm field experiments that showed decreases in sGSL abundance per cell subject to EhV infection (Fulton et al., 2014); these results were interpreted as preferential infection of sGSL rich cells and relative growth of sGSL poor virus resistant cells. In light of our finding that sGSL is absent in $1 \mathrm{~N}$ cells, the interpretation of Fulton et al. (2014) is entirely consistent with the observations of Frada et al. (2012) from the same mesocosms showing that $1 \mathrm{~N}$ cells became proportionally more abundant, an affirmation of the Cheshire Cat hypothesis (Frada et al., 2008). Although the dynamics of sGSL subject to EhV infection appear variable between $2 \mathrm{~N}$ systems (Fulton et al., 2014), the discovery here that sGSL is absent in $1 \mathrm{~N}$ E. huxleyi cells could make sGSL an even more important biomarker for viral infection dynamics and associated shifts in ploidy.

Since $1 \mathrm{~N}$ cells are resistant to viral infection (Frada et al., 2008) and sGSL is linked with susceptibility in several strains of 2N E. huxleyi (Fulton et al., 2014), the absence of sGSL from $1 \mathrm{~N}$ cells further implicates sGSL as playing a key role in viral infection (Fulton et al., 2014). Sialic acid moieties similar to that of sGSL are implicated as ligands for viral attachment in the cyanobacterium Prochlorococcus (Avrani et al., 2011; Fulton et al., 2014). It has been speculated therefore, that viral attachment and entry, facilitated by sGSL, may be the means by which this resistance is achieved (Fulton et al., 2014). Furthermore, it has been speculated that sGSL may have intrinsic function in the production or externalization of the coccoliths that characterize the exterior of the calcifying $2 \mathrm{~N}$ phase (Fulton et al., 2014). It is noteworthy therefore, that the $1 \mathrm{~N}$ phase that does not produce sGSL also does not produce coccoliths, further suggesting a link between sGSL and calcification.

\section{Untargeted Lipidomics and Biomarker Selection}

By using PLS-DA to analyse the untargeted lipidomic data, we have highlighted molecular species diagnostic of each $1 \mathrm{~N}, 2 \mathrm{~N}$, and infected $2 \mathrm{~N}$ cells (Table 1 ). These species were assigned identities based upon matches between accurate $\mathrm{m} / \mathrm{z}$ and an extensive database of lipids. The included assignments are supported by secondary $\mathrm{MS}^{2}$ data. Due to the nature of the all ion fragmentation $\mathrm{MS}^{2}$ method applied in the interest of unbiased methodology, incorrect assignments of co-eluting species may occur in some cases. As such the assigned lipid identities in the unbiased analyses are presented as tentative. The differential abundances of each species give a quantitative representation for the discovery of potential biomarkers.

For the uninfected $2 \mathrm{~N}$ control, the known susceptibility biomarker sGSL (Fulton et al., 2014) and related species were the top ranked assigned hits, in both positive and negative ion mode. This observation is in agreement with the targeted data, where sGSL was absent from the uninfected $1 \mathrm{~N}$ cultures, and reduced in abundance in the infected $2 \mathrm{~N}$ case. In negative ion mode, $\mathrm{BLL}(18: 1 / 22: 6)$ was ranked $3 \mathrm{rd}$ for the uninfected $2 \mathrm{~N}$ cultures. BLL(18:1/22:6) is a known marker of E. huxleyi, whose concentration has been shown to drop under viral infection (Fulton et al., 2014). At the present time, sGSL and BLL (18:1/22:6) have not been reported in any other species than $E$. huxleyi. By contrast, PC(34:5), MGDG(36:9), and SQDG(40:8) which were ranked 5 th in positive, 4 th and 5 th in negative ion mode respectively, are common polar membrane glycerolipids in eukaryotic microalgae (Popendorf et al., 2011a; Brandsma et al., 2012). These observations underscore the challenge of developing these biomarkers for use in the field: a molecule must be both diagnostic for E. huxleyi viral infection and ploidy and absent in all other marine microbes. The former criterion is addressed with the data presented here, but the latter will only be met after the lipidomes of many additional marine taxa are examined using the techniques similar to those employed here. In the meantime, the biomarkers we identified by untargeted lipidomics should be applied with due discretion.

In the uninfected $1 \mathrm{~N}$ cultures, the top hits in positive ion mode appeared to be a form of 31:0 wax ester or alkenoate. It is possible that changes in this molecule could reflect differences in the amounts of long chain alkenones in $1 \mathrm{~N}$ cells. Alkenones are widely used in palaeoceanography temperature reconstructions (Volkman et al., 1980; Prahl and Wakeham, 1987). Direct comparisons between this 31:0 wax ester/alkenoate and alkenones remain to be conducted.

The 3rd and 4th ranked species in $1 \mathrm{~N}$ cultures in positive ion mode were matched to a GSL(t40:0) and GSL(t40:1) species. These GSLs appear to share some structural similarities with archetypal forms of hGSL (GSL $(\mathrm{d} 41: 5(\mathrm{OH})$ ) and vGSL (GSL(t39:0(OH)) identified by Vardi et al. (2009, 2012). These haploid specific GSLs may be the source of the observed vGSL-like species in the targeted uninfected haploid analyses, discussed previously. In light of the aforementioned targeted GSL data, these haploid GSLs certainly warrant further characterization. In negative ion mode, $\operatorname{Cer}(\mathrm{d} 18: 1 / 22: 0(\mathrm{OH}))$ and Cer(d18:1/22:1(OH)) hydroxyceramide species were ranked 2nd and $3 \mathrm{rd}$ for the uninfected $1 \mathrm{~N}$ cultures. These ceramides are effectively the same chemical composition as GSL minus the glycosyl headgroup. Furthermore, it is likely that the GSL(t40:1) highlighted is in fact the $\operatorname{Cer}(\mathrm{d} 18: 1 / 22: 0(\mathrm{OH}))$ ceramide moiety with a glycosyl headgroup, although this could not be confirmed from the MS2 data. Interestingly, upregulation of enzymes responsible for the production of ceramides from the hydrolysis of the beta-glycosidic linkages of GSLs is a characteristic response of $2 \mathrm{~N}$ cells to viral infection (Rosenwasser et al., 2014). To our knowledge, the GSL(t40:0) and GSL(t40:1) species have not been previously reported in any marine microbial organism, 
although they are closely related chemically to the other GSLs. Thus, these GSL species represent, pending further validation and characterization, candidate biomarkers for $1 \mathrm{~N}$ E. huxleyi. $1 \mathrm{~N}$ E. huxleyi are not easily identifiable in field samples by classic microscopy techniques (Von Dassow et al., 2009) and lipid biomarkers have particular utility in bulk environmental samples, such as filtered particulate organic material collected from the water column or sinking particulate trap matter, where other methods may not be applicable.

Finally, a number of glyceroglycolipids appeared indicative of the uninfected $1 \mathrm{~N}$ cultures. MGDG(32:5) was ranked 5th in positive ion mode and LMGDG(22:6), DGDG(32:5) and DGDG(30:6) were ranked 1st, 4 th, and 5th in negative ion mode. Glyceroglycolipids are typically associated with the thylakoid membranes of the chloroplast (Petroutsos et al., 2014). Our analysis highlights differences in these photosynthetic membrane lipids and alludes to some implication of ploidy upon the photosynthetic apparatus. However, these are fairly common molecules that are unlikely to be of much utility as biomarkers for E. huxleyi viral infection or ploidy (Popendorf et al., 2011a; Brandsma et al., 2012).

For the infected $2 \mathrm{~N}$ cultures, the PLS-DA model highlights a series of TAGs found under positive ionization as indicative. TAG biosynthesis is commonly upregulated in phytoplankton in response to a variety of stressors, and TAGs are found primarily in lipid bodies. TAGs are unlikely to be attributable to heterotrophic bacterial contaminants as they are not generally produced in significant quantities by bacteria (Alvarez and Steinbüchel, 2002). It has been proposed that EhV capsid assembly occurs via a mechanism similar to that of the Hepatitis C virus (Herker and Ott, 2011; Fulton et al., 2014), where lipids are incorporated from the interface of lipid bodies and the endoplasmic reticulum. In uninfected $2 \mathrm{~N}$ E. huxleyi, these lipid bodies are composed mainly of alkenones, alkenoates, and small quantities of TAGs and other lipids (Eltgroth et al., 2005). Research on human hepatocyte cells shows that TAGs are critical to Hepatitis C capsid assembly (Liefhebber et al., 2014). Thus, we speculate that the observed increase in a number of TAG species in E. huxleyi under EhV infection may result from the virus upregulating TAG biosynthesis in order to assist capsid assembly.

In negative ion mode, vGSL and $\operatorname{BLL}(22: 6 / 22: 6)$ represent the top four assigned species indicative of the infected cultures, in line with previous observations (Vardi et al., 2012; Fulton et al., 2014) and the targeted data discussed previously, while a 36:2 wax ester/alkenoate species is ranked fifth. None of these molecules are likely to be derived from contaminating bacteria in the cultures, but instead are of decidedly coccolithophore origin (Eltgroth et al., 2005; Fulton et al., 2014; Ray et al., 2014). A molecule with the exact same elemental formula, 36:2 methyl alkenoate, was identified in E. huxleyi lipid bodies (Eltgroth et al., 2005). Closely related alkenones are abundant in EhV virions and alkenone content in infected E. huxleyi has previously been demonstrated to be increased (Fulton et al., 2014). As mentioned previously, alkenoates and alkenones are thought to occur primarily in lipid bodies (Eltgroth et al., 2005). We suggest therefore, that this $36: 2$ wax ester/alkenoate species we observed was likely localized to lipid bodies. If true, this result, in conjunction with the TAG data mentioned above, further implicates the role of lipid bodies in viral assembly (Fulton et al., 2014).

In addition to the assigned species discussed previously, many novel biomarkers could not be assigned from our database and/or corroborated by all ion fragmentation $\mathrm{MS}^{2}$ (Supplementary Table 2). Many of these species demonstrate absence/presence behavior between cultures and have potential as biomarkers of EhV infection or ploidy in E. huxleyi. The assigned and unassigned candidate biomarkers discovered by these unbiased analyses are tantalizing. A further biomarker validation study, utilizing targeted $\mathrm{MS}^{2} / \mathrm{MS}^{3}$ fragmentation in conjunction with high resolution mass spectrometry has the potential to assign and confirm the identities of the additional molecular species.

\section{CONCLUSIONS}

We have presented critical new data on the glycerolipids and glycosphingolipids of $1 \mathrm{~N} E$. huxleyi by the application of a targeted lipidomics approach. Comparison of these data to that of infected and uninfected $2 \mathrm{~N} \mathrm{E}$. huxleyi has provided new insights on ploidy and viral infection. Firstly, we note the detection of trace levels of the EhV type viral glycosphingolipid (vGSL) in the uninfected $1 \mathrm{~N}$ samples. The implications of this observation are as yet unclear but should be considered in the application of vGSL as a biomarker of EhV infection. Secondly, we find that the sialic glycosphingolipid (sGSL), a proposed marker of susceptibility to EhV infection in E. huxleyi, was absent from the uninfected $1 \mathrm{~N}$ cell. This absence provides further evidence for the role of sGSL in EhV infection and may confer $1 \mathrm{~N}$ E. huxleyi its documented resistance to $\mathrm{EhV}$.

In addition, we have highlighted promising lipid biomarker candidates for each of the uninfected $2 \mathrm{~N}, 1 \mathrm{~N}$, and infected $2 \mathrm{~N}$ cases by way of untargeted lipidomics. Differentially enriched biomarker candidates have been tentatively identified, such as novel glycosphingolipids, hydroxyceramides and a wax ester/alkanoate that are highly indicative of the $1 \mathrm{~N}$ phase. Following further biomarker validation and structural studies these lipids may yield powerful lipid biomarkers for the determination of $1 \mathrm{~N}$ E. huxleyi, identification of which is not feasible by classic microscopy techniques.

These findings contribute to our understanding of the critical role of lipids in E. huxleyi/EhV interactions. Moreover, our findings further the potential of lipid based biomarkers as indicators of the progression of infection and life cycle in $E$. huxleyi. Extrapolation from simplified cell culture models to complex environmental systems must be approached with due caution and the discussed biomarkers require further validation in culture and in situ. However, such biomarkers have the potential to yield great insight into the processes that dictate the characteristics of E. huxleyi blooms, translating to substantial implications for global carbon cycling and climate.

\section{ACKNOWLEDGMENTS}

The authors would like to thank J. Tagliafere and J. Ossolinski for assistance in the laboratory and J. Collins, J. Fulton, and B. Edwards for helpful discussions about data analysis. This work was funded by the University of Southampton-Vice Chancellor's 
Scholarship Award (JH), University of Southampton-Diamond Jubilee Fellowship (BV), Graduate School of the National Oceanography Centre WHOI Exchange Award (JH), and the Gordon and Betty Moore Foundation through Grant GBMF3301 (BV and $\mathrm{AV}$ ).

\section{REFERENCES}

Alvarez, H., and Steinbüchel, A. (2002). Triacylglycerols in prokaryotic microorganisms. Appl. Microbiol. Biotechnol. 60, 367-376. doi: 10.1007/s00253002-1135-0

Avrani, S., Wurtzel, O., Sharon, I., Sorek, R., and Lindell, D. (2011). Genomic island variability facilitates Prochlorococcus-virus coexistence. Nature 474, 604-608. doi: 10.1038/nature10172

Ballabio, D., and Consonni, V. (2013). Classification tools in chemistry. Part 1: linear models. PLS-DA. Anal. Methods 5, 3790-3798. doi: 10.1039/C3AY40582F

Bell, M. V., and Pond, D. (1996). Lipid composition during growth of motile and coccolith forms of Emiliania huxleyi. Phytochemistry 41, 465-471. doi: 10.1016/0031-9422(95)00663-X

Bligh, E. G., and Dyer, W. J. (1959). A rapid method of total lipid extraction and purification. Can. J. Biochem. Physiol. 37, 911-917. doi: 10.1139/o59-099

Borchard, C., and Engle, A. (2012). Organic matter exudation by Emiliania huxleyi under simulated future ocean conditions. Biogeosciences 9, 3405-3423. doi: 10.5194/bg-9-3405-2012

Brandsma, J., Hopmans, E. C., Philippart, C. J. M., Veldhuis, M. J. W., Schouten, S., and Sinninghe Damsté, J. S. (2012). Low temporal variation in the intact polar lipid composition of North Sea coastal marine water reveals limited chemotaxonomic value. Biogeosciences 9, 1073-1084. doi: 10.5194/bg-9-10 73-2012

Bratbak, G., Egge, J. K., and Heldal, M. (1993). Viral mortality of the marine alga Emiliania huxleyi (Haptophyceae) and termination of algal blooms. Mar. Ecol. Prog. Ser. 93, 39-48. doi: 10.3354/meps093039

Brussaard, C., Gast, G., van Duyl, F., and Riegman, R. (1996). Impact of phytoplankton bloom magnitude on a pelagic microbial food web. Mar. Ecol. Prog. Ser. 144, 211-221. doi: 10.3354/meps144211

Carini, P., Van Mooy, B. A. S., Thrash, J. C., White, A., Zhao, Y., Campbell, E. O., et al. (2015). SAR11 lipid renovation in response to phosphate starvation. Proc. Natl. Acad. Sci. U.S.A. 112, 7767-7772. doi: 10.1073/pnas.1505034112

Eltgroth, M. L., Watwood, R. L., and Wolfe, G. V. (2005). Production and cellular localization of neutral long-chain lipids in the haptophyte algae isochrysis galbana and Emiliania huxleyi. J. Phycol. 41, 1000-1009. doi: 10.1111/j.15298817.2005.00128.x

Frada, M. J., Bidle, K. D., Probert, I., and de Vargas, C. (2012). In situ survey of life cycle phases of the coccolithophore Emiliania huxleyi (Haptophyta). Environ. Microbiol. 14, 1558-1569. doi: 10.1111/j.1462-2920.2012.02745.x

Frada, M., Probert, I., Allen, M. J., Wilson, W. H., and de Vargas, C. (2008). The "Cheshire Cat" escape strategy of the coccolithophore Emiliania huxleyi in response to viral infection. Proc. Natl. Acad. Sci. U.S.A. 105, 15944-15949. doi: 10.1073/pnas.0807707105

Fuhrman, J. A. (1999). Marine viruses and their biogeochemical and ecological effects. Nature 399, 541-548. doi: 10.1038/21119

Fulton, J. M., Fredricks, H. F., Bidle, K. D., Vardi, A., Kendrick, B. J., DiTullio, G. R., et al. (2014). Novel molecular determinants of viral susceptibility and resistance in the lipidome of Emiliania huxleyi. Environ. Microbiol. 16, 1137-1149. doi: 10.1111/1462-2920.12358

Green, J. C., Course, P. A., and Tarran, G. A. (1996). The life-cycle of Emiliania huxleyi: a brief review and a study of relative ploidy levels analysed by flow cytometry. J. Mar. Syst. 9, 33-44. doi: 10.1016/0924-7963(96) 00014-0

Gundersen, K., Heldal, M., Norland, S., Purdie, D. A., and Knap, A. H. (2002). Elemental C, N, and P content of individual bacteria collected at the Bermuda Atlantic Time-Series (BATS) site. Limnol. Oceanogr. 47, 1525-1530. doi: 10.4319/lo.2002.47.5.1525

\section{SUPPLEMENTARY MATERIAL}

The Supplementary Material for this article can be found online at: http://journal.frontiersin.org/article/10.3389/fmars. 2015.00081

Herker, E., and Ott, M. (2011). Unique ties between hepatitis C virus replication and intracellular lipids. Trends Endocrinol. Metab. 22, 241-248. doi: 10.1016/j.tem.2011.03.004

Holligan, P. M., Viollier, M., Harbour, D. S., Camus, P., and Champagne-Philippe, M. (1983). Satellite and ship studies of coccolithophore production along a continental shelf edge. Nature 304, 339-342. doi: 10.1038/304339a0

Houdan, A., Billard, C., Marie, D., Not, F., Sáez, A. G., Young, J. R., et al. (2004). Holococcolithophore-heterococcolithophore (Haptophyta) life cycles: flow cytometric analysis of relative ploidy levels. Syst. Biodivers. 1, 453-465. doi 10.1017/S1477200003001270

Houdan, A., Probert, I., Van Lenning, K., and Lefebvre, S. (2005). Comparison of photosynthetic responses in diploid and haploid life-cycle phases of Emiliania huxleyi (Prymnesiophyceae). Mar. Ecol. Prog. Ser. 292, 139-146. doi: 10.3354/meps292139

Huang, N., Siegel, M. M., Kruppa, G. H., and Laukien, F. H. (1999). Automation of a Fourier transform ion cyclotron resonance mass spectrometer for acquisition, analysis, and e-mailing of high-resolution exact-mass electrospray ionization mass spectral data. J. Am. Soc. Mass Spectrom. 10, 1166-1173. doi: 10.1016/S1044-0305(99)00089-6

Hummel, J., Segu, S., Li, Y., Irgang, S., Jueppner, J., and Giavalisco, P. (2011). Ultra performance liquid chromatography and high resolution mass spectrometry for the analysis of plant lipids. Front. Plant Sci. 2:54. doi: 10.3389/fpls.2011. 00054

Jover, L. F., Effler, T. C., Buchan, A., Wilhelm, S. W., and Weitz, J. S. (2014). The elemental composition of virus particles: implications for marine biogeochemical cycles. Nat. Rev. Micro. 12, 519-528. doi: 10.1038/nrmicro3289

Keller, M. D., Selvin, R. C., Claus, W., and Guillard, R. R. L. (1987). Media for the culture of oceanic ultraphytoplankton. J. Phycol. 23, 633-638. doi: 10.1111/j.1529-8817.1987.tb04217.x

Klaveness, D. (1972). Coccolithus huxleyi (Lohm.) Kamptn II. The flagellate cell, aberrant cell types, vegetative propagation and life cycles. Br. Phycol. J. 7, 309-318. doi: 10.1080/00071617200650321

Lehahn, Y., Koren, I., Schatz, D., Frada, M., Sheyn, U., Boss, E., et al. (2014). Decoupling physical from biological processes to assess the impact of viruses on a mesoscale algal bloom. Curr. Biol. 24, 2041-2046. doi: 10.1016/j.cub.2014.07.046

Liefhebber, J. M. P., Hague, C. V., Zhang, Q., Wakelam, M. J. O., and McLauchlan, J. (2014). Modulation of triglyceride and cholesterol ester synthesis impairs assembly of infectious Hepatitis C virus. J. Biol. Chem. 289, 21276-21288. doi: 10.1074/jbc.M114.582999

Mackinder, L. C. M., Worthy, C. A., Biggi, G., Hall, M., Ryan, K. P., Varsani, A., et al. (2009). A unicellular algal virus, Emiliania huxleyi virus 86, exploits an animal-like infection strategy. J. Gen. Virol. 90, 2306-2316. doi: 10.1099/vir.0.011635-0

Martin, P., Van Mooy, B. A. S., Heithoff, A., and Dyhrman, S. T. (2011) Phosphorus supply drives rapid turnover of membrane phospholipids in the diatom Thalassiosira pseudonana. ISME J. 5, 1057-1060. doi: 10.1038/ismej.2010.192

Mausz, M. A., and Pohnert, G. (2014). Phenotypic diversity of diploid and haploid Emiliania huxleyi cells and of cells in different growth phases revealed by comparative metabolomics. J. Plant Physiol. 172, 137-148. doi: 10.1016/j.jplph.2014.05.014

Monier, A., Pagarete, A., de Vargas, C., Allen, M. J., Read, B., Claverie, J. -M., et al. (2009). Horizontal gene transfer of an entire metabolic pathway between a eukaryotic alga and its DNA virus. Genome Res. 19, 1441-1449. doi: 10.1101/gr.091686.109

Paasche, E. (2001). A review of the coccolithophorid Emiliania huxleyi (Prymnesiophyceae), with particular reference to growth, coccolith formation, 
and calcification-photosynthesis interactions. Phycologia 40, 503-529. doi: 10.2216/i0031-8884-40-6-503.1

Petroutsos, D., Amiar, S., Abida, H., Dolch, L.-J., Bastien, O., Rébeillé, F., et al. (2014). Evolution of galactoglycerolipid biosynthetic pathways-From cyanobacteria to primary plastids and from primary to secondary plastids. Prog. Lipid Res. 54, 68-85. doi: 10.1016/j.plipres.2014.02.001

Popendorf, K. J., Fredricks, H. F., and Van Mooy, B. A. S. (2013). Molecular ionindependent quantification of polar glycerolipid classes in marine plankton using triple quadrupole MS. Lipids 48, 185-195. doi: 10.1007/s11745-01 2-3748-0

Popendorf, K. J., Lomas, M. W., and Van Mooy, B. A. S. (2011a). Microbial sources of intact polar diacylglycerolipids in the Western North Atlantic Ocean. Org. Geochem. 42, 803-811. doi: 10.1016/j.orggeochem.2011.05.003

Popendorf, K. J., Tanaka, T., Pujo-Pay, M., Lagaria, A., Courties, C., Conan, P., et al. (2011b). Gradients in intact polar diacylglycerolipids across the Mediterranean Sea are related to phosphate availability. Biogeosciences 8, 3733-3745. doi: 10.5194/bg-8-3733-2011

Prahl, F. G., and Wakeham, S. G. (1987). Calibration of unsaturation patterns in long-chain ketone compositions for palaeotemperature assessment. Nature 330, 367-369. doi: 10.1038/330367a0

Ray, J. L., Haramaty, L., Thyrhaug, R., Fredricks, H. F., Van Mooy, B. A. S., Larsen, A., et al. (2014). Virus infection of Haptolina ericina and Phaeocystis pouchetii implicates evolutionary conservation of programmed cell death induction in marine haptophyte-virus interactions. J. Plankton Res. 36, 943-955. doi: 10.1093/plankt/fbu029

Rokitta, S. D., de Nooijer, L. J., Trimborn, S., de Vargas, C., Rost, B., and John, U. (2011). Transcriptome analyses reveal differential gene expression patterns between the life-cycle stages of Emiliania huxleyi (Haptophyta) and reflect specialization to different ecological niches. J. Phycol. 47, 829-838. doi: 10.1111/j.1529-8817.2011.01014.x

Rose, S. L., Fulton, J. M., Brown, C. M., Natale, F., Van Mooy, B. A. S., and Bidle, K. D. (2014). Isolation and characterization of lipid rafts in Emiliania huxleyi: a role for membrane microdomains in host-virus interactions. Environ. Microbiol. 16, 1150-1166. doi: 10.1111/1462-2920.12357

Rosenwasser, S., Mausz, M. A., Schatz, D., Sheyn, U., Malitsky, S., Aharoni, A., et al. (2014). Rewiring host lipid metabolism by large viruses determines the fate of Emiliania huxleyi, a bloom-forming alga in the Ocean. Plant Cell 26, 2689-2707. doi: 10.1105/tpc.114.125641

Sakurai, I., Shen, J.-R., Leng, J., Ohashi, S., Kobayashi, M., and Wada, H. (2006). Lipids in oxygen-evolving photosystem II complexes of cyanobacteria and higher plants. J. Biochem. 140, 201-209. doi: 10.1093/jb/mvj141

Schatz, D., Shemi, A., Rosenwasser, S., Sabanay, H., Wolf, S. G., Ben-Dor, S., et al. (2014). Hijacking of an autophagy-like process is critical for the life cycle of a DNA virus infecting oceanic algal blooms. New Phytol. 204, 854-863. doi: 10.1111/nph.13008

Schroeder, D. C., Oke, J., Malin, G., and Wilson, W. H. (2002). Coccolithovirus (Phycodnaviridae): characterisation of a new large dsDNA algal virus that infects Emiliana huxleyi. Arch. Virol. 147, 1685-1698. doi: 10.1007/s00705-0020841-3

Shemi, A., Ben-Dor, S., and Vardi, A. (2015). Elucidating the composition and conservation of the autophagy pathway in photosynthetic eukaryotes. Autophagy 11, 701-715. doi: 10.1080/15548627.2015.1034407

Stray, S. J., Cummings, R. D., and Air, G. M. (2000). Influenza virus infection of desialylated cells. Glycobiology 10, 649-658. doi: 10.1093/glycob/10.7.649

Sud, M., Fahy, E., Cotter, D., Brown, A., Dennis, E. A., Glass, C. K., et al. (2007). LMSD: LIPID MAPS structure database. Nucleic Acids Res. 35, D527-D532. doi: $10.1093 / \mathrm{nar} / \mathrm{gkl} 838$

Suttle, C. A. (2007). Marine viruses-major players in the global ecosystem. Nat. Rev. Micro. 5, 801-812. doi: 10.1038/nrmicro1750
Tyrrell, T., and Merico, A. (2004). "Emiliania huxleyi: bloom observations and the conditions that induce them," in Coccolithophores SE-4 eds H. R. Thierstein and J. R. Young (Berlin; Heidelberg: Springer), 75-97.

Van den Berg, R. A., Hoefsloot, H. C. J., Westerhuis, J. A., Smilde, A. K., and van der Werf, M. J. (2006). Centering, scaling, and transformations: improving the biological information content of metabolomics data. BMC Genomics 7:142. doi: 10.1186/1471-2164-7-142

Van Etten, J. L., Graves, M. V., Müller, D. G., Boland, W., and Delaroque, N. (2002). Phycodnaviridae- large DNA algal viruses. Arch. Virol. 147, 1479-1516. doi: 10.1007/s00705-002-0822-6

Van Mooy, B. A. S., Fredricks, H. F., Pedler, B. E., Dyhrman, S. T., Karl, D. M., Koblížek, M., et al. (2009). Phytoplankton in the ocean use nonphosphorus lipids in response to phosphorus scarcity. Nature 458, 69-72. doi: 10.1038 /nature07659

Vardi, A., Haramaty, L., Van Mooy, B. A. S., Fredricks, H. F., Kimmance, S. A., Larsen, A., et al. (2012). Host-virus dynamics and subcellular controls of cell fate in a natural coccolithophore population. Proc. Natl. Acad. Sci. U.S.A. 109, 19327-19332. doi: 10.1073/pnas.1208895109

Vardi, A., Van Mooy, B. A. S., Fredricks, H. F., Popendorf, K. J., Ossolinski, J. E., Haramaty, L., et al. (2009). Viral glycosphingolipids induce lytic infection and cell death in marine phytoplankton. Science 326, 861-865. doi: $10.1126 /$ science. 1177322

Volkman, J. K., Eglinton, G., Corner, E. D. S., and Sargent, J. R. (1980). Novel unsaturated straight-chain C37-C39 methyl and ethyl ketones in marine sediments and a coccolithophore Emiliania huxleyi. Phys. Chem. Earth 12, 219-227. doi: 10.1016/0079-1946(79)90106-x

Von Dassow, P., Ogata, H., Probert, I., Wincker, P., Da Silva, C., Audic, S., et al. (2009). Transcriptome analysis of functional differentiation between haploid and diploid cells of Emiliania huxleyi, a globally significant photosynthetic calcifying cell. Genome Biol. 10, 1-33. doi: 10.1186/gb-2009-1 $0-10-\mathrm{r} 114$

Weber, R. J. M., Li, E., Bruty, J., He, S., and Viant, M. R. (2012). MaConDa: a publicly accessible mass spectrometry contaminants database. Bioinformatics 28, 2856-2857. doi: 10.1093/bioinformatics/bts527

Westbroek, P., Brown, C. W., van Bleijswijk, J., Brownlee, C., Brummer, G. J., Conte, M., et al. (1993). A model system approach to biological climate forcing. The example of Emiliania huxleyi. Glob. Planet. Change 8, 27-46. doi: 10.1016/0921-8181(93)90061-R

Wilson, W. H., Schroeder, D. C., Allen, M. J., Holden, M. T. G., Parkhill J., Barrell, B. G., et al. (2005). Complete genome sequence and lytic phase transcription profile of a coccolithovirus. Science 309, 1090-1092. doi: 10.1126/science.1113109

Wilson, W. H., Tarran, G. A., Schroeder, D., Cox, M., Oke, J., and Malin, G. (2002). Isolation of viruses responsible for the demise of an Emiliania huxleyi bloom in the English Channel. J. Mar. Biol. Assoc. U.K. 82, 369-377. doi: $10.1017 /$ S002531540200560X

Conflict of Interest Statement: The authors declare that the research was conducted in the absence of any commercial or financial relationships that could be construed as a potential conflict of interest.

Copyright (c) 2015 Hunter, Frada, Fredricks, Vardi and Van Mooy. This is an openaccess article distributed under the terms of the Creative Commons Attribution License (CC BY). The use, distribution or reproduction in other forums is permitted, provided the original author(s) or licensor are credited and that the original publication in this journal is cited, in accordance with accepted academic practice. No use, distribution or reproduction is permitted which does not comply with these terms. 